\title{
Rancang Bangun Alat Ukur Viskositas Darah Berbasis Metode Falling Ball Viscometer Small Tube Menggunakan Transmisi Ethernet Shield
}

\author{
Novia Ratna Dewita*, Harmadi \\ Jurusan Fisika FMIPA Universitas Andalas \\ Kampus Unand Limau Manis, Pauh Padang 25163 \\ *noviaratde@gmail.com
}

\begin{abstract}
ABSTRAK
Telah dirancang bangun alat ukur viskositas darah berbasis metode falling ball viscometer small tube menggunakan transmisi ethernet shield. Alat ini menggunakan tabung kaca dengan panjang $15 \mathrm{~cm}$, dan karet bola hisap diletakkan di atas tabung yang berfungsi untuk menarik bola besi dengan diameternya 5 $\mathrm{mm}$. Dua pasang sistem sensor yang terdiri dari sumber cahaya LED IR dan detektor cahaya fotodioda pada tabung dipasang sejajar. Ketika bola besi yang dijatuhkan dari karet bola hisap melewati sistem sensor pertama maka timer hidup, dan kemudian melewati sistem sensor kedua timer mati. waktu tempuh yang diperoleh dari sistem pertama dan kedua kemudian diolah oleh Arduino Uno dengan persamaan visikositas, dan ditampilkan pada LCD. Pengukuran dilakukan dengan dua variasi, yaitu variasi temperatur pada $30^{\circ} \mathrm{C}, 37^{\circ} \mathrm{C}$, dan $43^{\circ} \mathrm{C}$ dan variasi pencampuran EDTA $10 \%$ dengan jumlah EDTA $10 \mathrm{ml}, 20 \mathrm{ml}$, dan $30 \mathrm{ml}$. Nilai regresi yang diperoleh pada variasi temperatur sebesar 0,8882 dan pada variasi pencampuran darah dengan larutan EDTA $10 \%$ sebesar 0,866. Nilai viskositas darah juga bisa dilihat di komputer dengan menggunakan Ethernet shield.

Kata kunci: falling ball viscometer, small tube, viskositas
\end{abstract}

\section{ABSTRACT}

Designing a blood viscosity measuring devices based on falling ball viscometer small tube method using an ethernet shield transmission has been done. This tool uses a glass tube with a length of $15 \mathrm{~cm}$, and suction ball rubber is placed on the top of the tube which serves to draw an iron ball with a diameter of 5 mm. Two pairs of sensor systems consisting of an IR LED light source and photodiode light detector on a parallel tube. When the iron ball dropped from the suction ball rubber passes through the first sensor system then the timer is on, and passes through the sensor system the two timers turn off. The time obtained from the first and second systems is then processed by Arduino Uno, and is displayed in the form of a viscosity value on the LCD. Measurements were made by varying the temperatures of $30^{\circ} \mathrm{C}, 37^{\circ} \mathrm{C}$, and $43^{\circ} \mathrm{C}$ with the regression values obtained ie 0.8882 and varying the mixing of blood with $10 \%$ with varying $10 \mathrm{ml}, 20 \mathrm{ml}, 30 \mathrm{ml}$. EDTA solution to determine the effect of blood dilution on blood viscosity with the regression value obtained is 0.86 . In addition, the value of blood viscosity can also be seen on computers using the Ethernet shield.

Keywords: falling ball viscometer, small tube, viscosity

\section{PENDAHULUAN}

Kekentalan (viskositas) merupakan fenomena fisis yang nilainya dapat diukur dalam penentuan sifat fluida. Fluida dengan nilai viskositas tinggi akan sulit untuk mengalir dan benda yang ada di dalamnya juga akan sulit bergerak. Viskositas adalah sifat fluida yang erat hubungannya dengan hambatan untuk mengalir, semakin tinggi kekentalan suatu fluida maka semakin besar hambatannya (Giancoli, 1998).

Viskositas darah merupakan acuan penting dalam dunia kesehatan untuk mengetahui kondisi seseorang. Penyakit kardiovaskular, serebrovaskular, diabetes, obesitas, syok hemoragik, oksidatif stress dan penyakit ginjal dinyatakan memiliki hubungan dengan peningkatan viskositas darah (Kim, dkk, 2016).

Orang dewasa memiliki volume darah yang mengalir di dalam sirkulasi mencapai 5-6 liter. Darah terus berputar mengalir di dalam sistem sirkulasi siskemik dan paru paru tanpa henti berfungsi untuk mengantar nutrisi dan oksigen ke seluruh tubuh yang dipompa oleh jantung. Pergeseran intern di dalam darah menyebabkan adanya sifat viskositas darah. Faktor penentu utama viskositas darah adalah hematokrit, agregasi sel darah merah, dan viskositas plasma (Kesmarky, 2008)

Penelitian untuk membuat alat ukur viskositas darah telah banyak dilakukan. Salah satunya adalah dengan membuat alat ukur viskositas darah menggunakan sistem Point of Care (POC). Sistem POC merupakan sistem pengukuran viskositas langsung berada disamping 
pasien. Alat ukur menggunakan tabung kecil (small tube) dengan menggunakan sampel darah 40 mikroliter dan waktu pengolahan data yang tidak lama. Metode yang digunakan falling ball small tube dengan Bovine Serum Albumin (BSA) sebagai lem perekat bola. Namun alat yang diciptakan hanya dapat digunakan sekali saja dan BSA yang digunakan dapat tercampur dengan darah. Selain itu alat ukur yang telah dibuat yaitu data keluaran nilai kekentalan hanya terbatas pada alat saja belum bisa dikirim ke tempat lain (Kim, 2016).

Alat ukur kekentalan darah non invasive dengan menggunakan sensor Plethysmograp (PPG) juga telah dikembangkan. Alat ukur yang dibuat cukup praktis tanpa harus mengambil sampel darah secara langsung. Alat ukur yang telah dibuat diletakkan pada jari, cara kerjanya yaitu sensor inframerah mengirimkan sinar pada jari tangan dan fototransistor menerima sebagian cahaya yang terpantulkan kembali. Intensitas cahaya yang terpantulkan tergantung pada kekentalan plasma darah, sehingga viskositas plasma darah menjadi parameter banyak tidaknya pantulan sinar inframerah yang dapat dideteksi oleh fototransistor. Kelemahan dari penelitian yang telah dilakukan yaitu kekentalan darah yang diukur hanya berdasarkan kekentalan plasma darah, bukan kekentalan darah keseluruhan dan nilai keluaran dari alat juga belum bisa dikirim ke tempat lain (Nurhandie, 2016).

Alat ukur kekentalan darah yang beredar sekarang masih kurang efektif. Seseorang yang mendonorkan darah untuk pasien yang sedang kritis, harus melakukan pemeriksaan kekentalan darah di laboratorium terlebih dahulu. Kekentalan darah diperiksa di laboratorium dan dibawa ke ruang tempat pengambilan darah dari pendonor, sehingga menghabiskan waktu yang lama.

Berdasarkan permasalahan dan hasil penelitian sebelumnya, dalam penelitian ini telah berhasil dirancang Alat Ukur Viskositas Darah Berbasis Metode Falling Ball Viscometer Small Tube Menggunakan Transmisi Ethernet Shield. Penelitan ini menggunakan darah golongan O sekitar 3 cc ditempatkan pada tabug kaca. Prinsip kerja dari alat ukur yang dibuat yaitu pertama, tabung kaca diisi darah sekitar 3 cc. Kedua, bola besi ditempatkan pada karet bola hisap diatas tabung, setelah itu bola dijatuhkan dari karet bola hisap. Bola besi melewati sistem sensor pertama dan dihitung sebagai waktu mulai, sedangkan ketika bola besi melewati sistem sensor yang kedua dihitung sebagai waktu akhir dari bola jatuh. Nilai keluaran dari alat diolah pada Ardiuno Uno dan ditampilkan di LCD, kemudian data yang diperoleh dari alat ukur dikirim kepada kemputer menggunakan Ethernet shield.

\section{METODE}

\subsection{Viskositas}

Bola bergerak cepat ketika dijatuhkan tetapi saat kecepatannya bertambah gaya Stokes juga bertambah, akibatnya bola mencapai keadaan seimbang sehingga bola bergerak dengan kecepatan konstan yang disebut dengan kecepatan terminal. Waktu $t$ detik bola telah mencapai kecepatan terminal $v$ dan telah menempuh jarak sebesar $d$ maka persamaan dapat ditulis sebagai:

$\eta=\frac{2 t r^{2} g}{9 d}\left(\rho_{b}-\rho_{f}\right)$

Dimana, $d$ merupakan jarak tempuh bola (m), $t$ merupakan waktu tempuh bola (s), $r$ merupakan jari-jari bola $(\mathrm{m}), g$ merupakan percepatan gravitasi $\left(\mathrm{m} / \mathrm{s}^{2}\right), \eta$ merupakan koefisien kekentalan $(\mathrm{Pa} \mathrm{s}), \rho_{\mathrm{b}}$ merupakan masa jenis bola $\left(\mathrm{kg} / \mathrm{m}^{3}\right), \rho_{\mathrm{f}}$ merupakan masa jenis fluida $\left(\mathrm{kg} / \mathrm{m}^{3}\right)$

\subsection{Perancangan Perangkat Keras Alat Ukur Viskositas Darah}

Perancangan perangkat keras alat ukur viskositas darah menggunakan metode falling ball viscometer small tube dibuat seperti Gambar 1. Sistem perangkat keras ini terdiri dari sistem sensor fotodioda dan LED IR, Arduino Uno, LCD.

Prinsip kerja dari alat ukur yang telah dibuat yaitu dua buah sensor fotodioda dipasang berhadap-hadapan dengan dua buah LED IR. Kemudian bola besi ditempatkan pada karet bola hisap. Ketika bola besi dijatuhkan dari karet bola hisap maka bola besi melewati sensor fotodioda yang pertama menyebabkan cahaya dari LED IR terhalang ke fotodioda, sehingga 
tegangan pada fotodioda bernilai 0 dan timer akan hidup. Ketika bola besi melewati fotodioda ke dua maka waktu timer akan berhenti. Waktu akhir dari timer ini diolah oleh Arduino Uno menjadi nilai viskositas darah. Hasilnya bisa ditampilkan di LCD dan bisa dilihat di PC. Penelitian ini dilakukan dengan dua variasi sampel yaitu variasi temperatur dan variasi pencampuran EDTA $10 \%$.

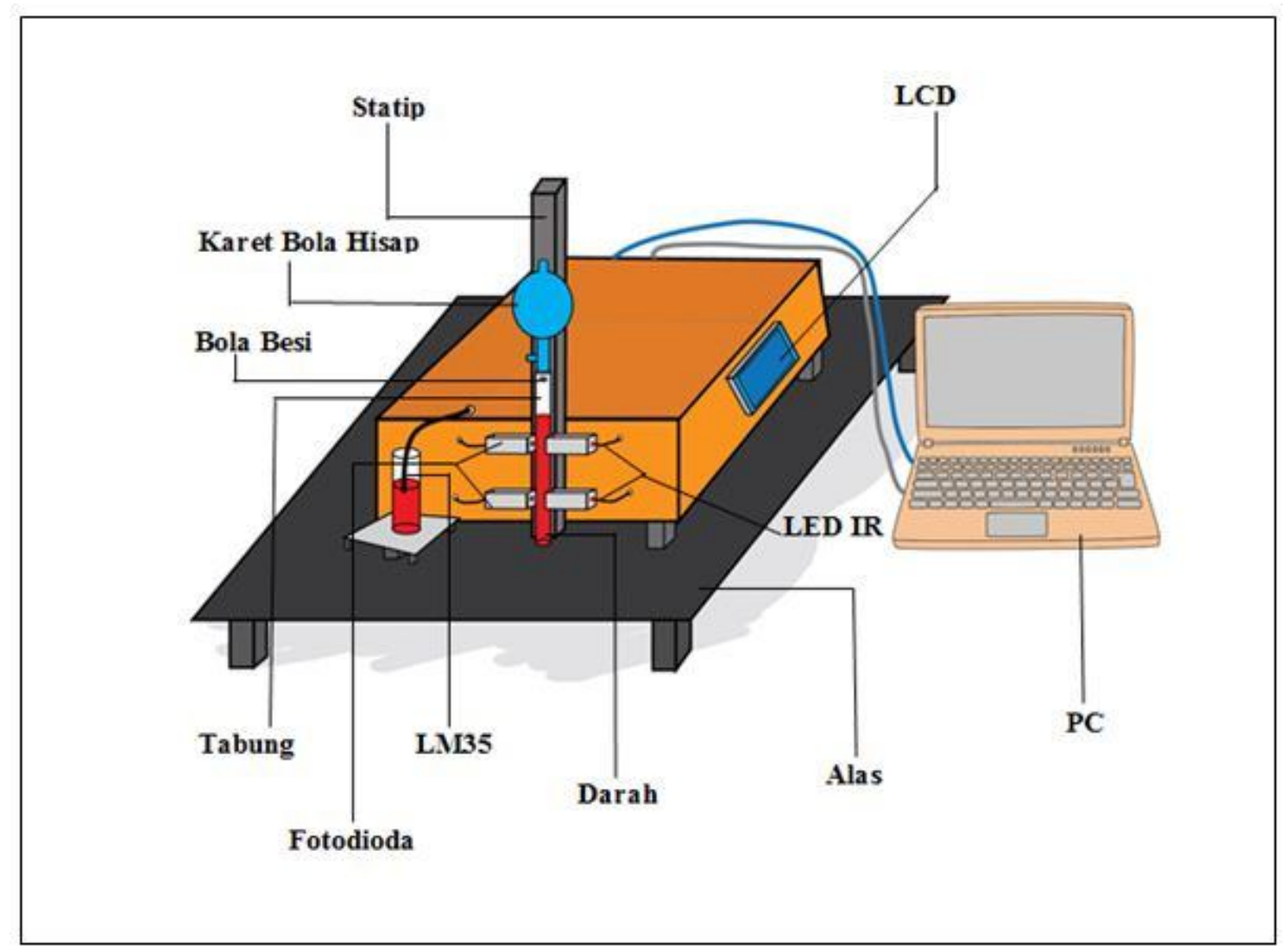

Gambar 1 Desain alat ukur viskositas darah

\subsection{Perancangan Perangkat Lunak Sistem Sensor}

Sistem perancangan perangkat lunak ini bertujuan untuk memproses sinyal masukan dari sensor fotodioda. Sistem alat ukur viskositas darah ditulis dalam bahasa C. Secara umum diagram alir program pengukuran viskositas darah pada Gambar 2.

Program memanggil prosedur dan fungsi yang diperlukan agar program dapat berjalan seperti yang kita inginkan. Inisialisasi ini meliputi pemanggilan prosedur untuk membaca data sensor, menampilkan data ke LCD, dan konstanta dan variabel yang digunakan dalam perancangan program. 


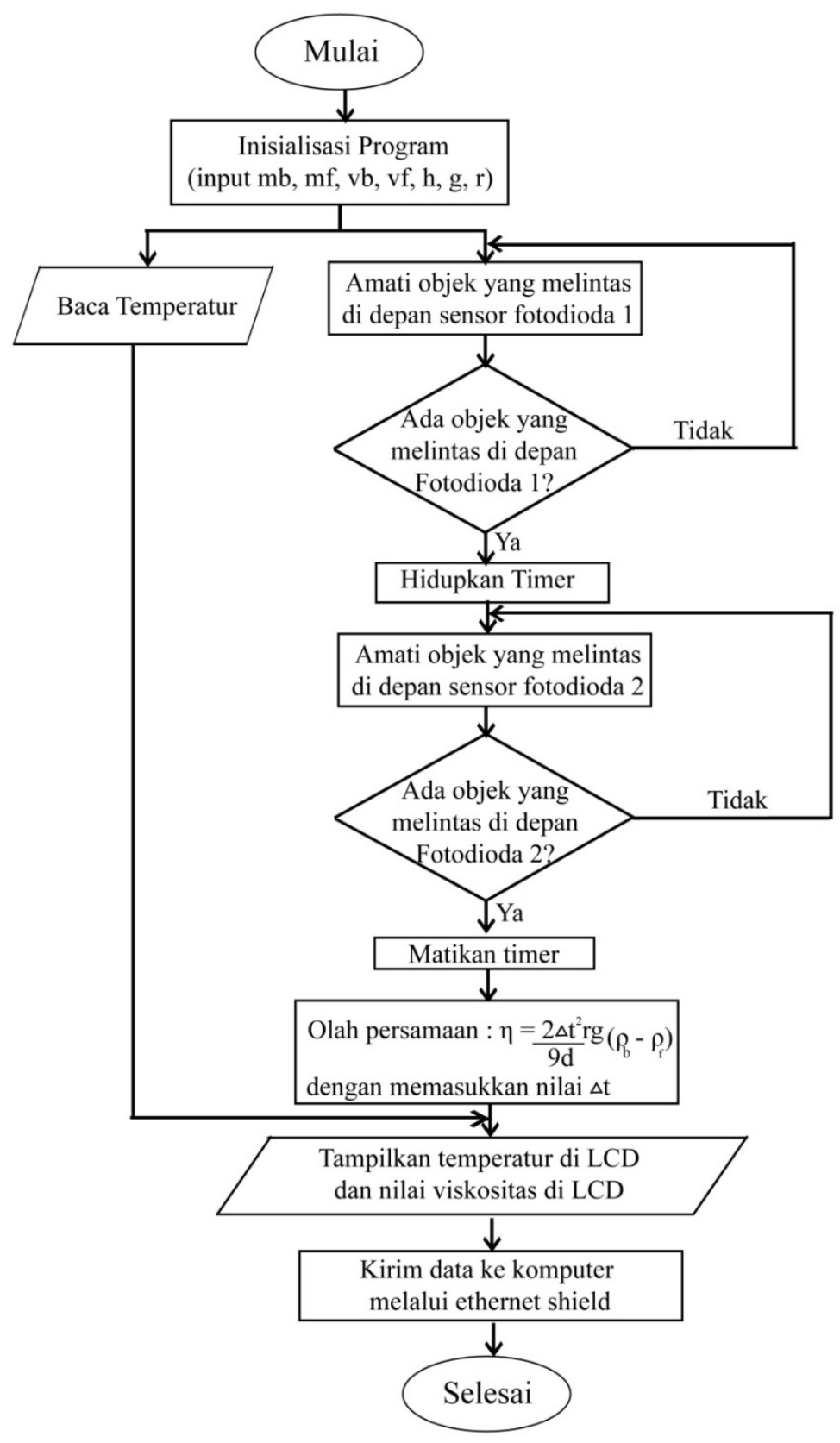

Gambar 2 Diagram alir pengukuran viskositas darah

\section{HASIL DAN DISKUSI}

\subsection{Pengujian Akhir Alat Ukur Viskositas Darah}

Pengujian alat berdasarkan variasi temperatur dilakukan dengan cara menaikkan temperatur darah. Darah di masukkan pada tabung kaca kemudian diletakkan pada wadah yang berisi air panas. Tabung kaca diangkat dari wadah ketika darah telah mencapai temperatur $30^{\circ} \mathrm{C}, 37^{\circ} \mathrm{C}, 43^{\circ} \mathrm{C}$.

Grafik hasil pengujian dari pengukuran viskositas darah dengan pengaruh variasi temperatur dilihat pada Gambar 3. Nilai viskositas yang didapatkan dari alat ukur yang dibuat menghasilkan nilai fungsi transfer $y=-1,313 x+152,98$ dengan nilai regresi 0,8882 . Dapat dilihat bahwa semakin tinggi temperatur maka semakin kecil nilai viskositasnya. 


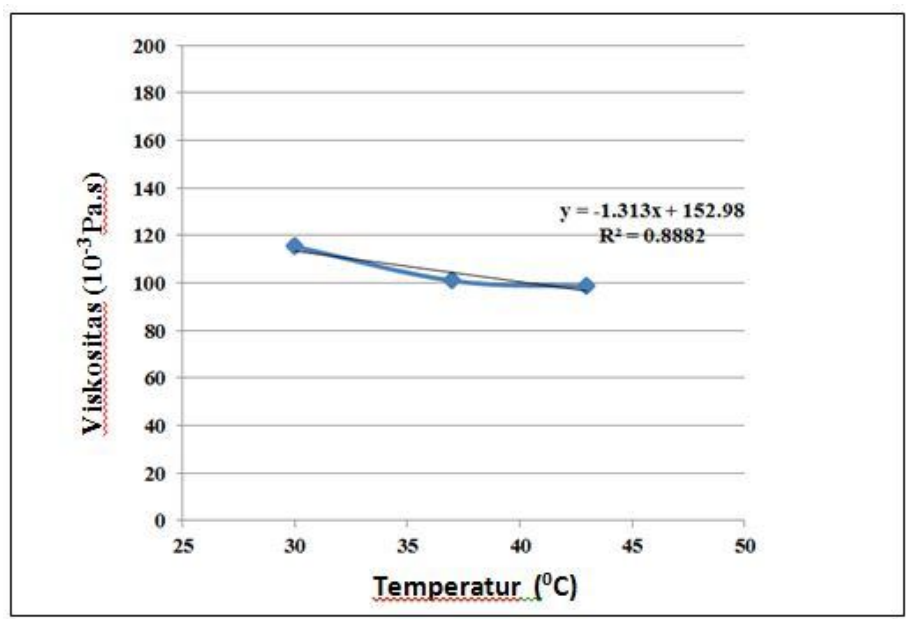

Gambar 3 Hasil pengujian viskositas darah menggunakan metode falling ball viscometer small tube variasi temperatur

Pengujian alat berdasarkan variasi pencampuran EDTA $10 \%$ dilakukan dengan cara mencampurkan darah sebanyak $40 \mathrm{ml}$ dengan EDTA 10\%. Volume EDTA 10\% divariasikan antara $0 \mathrm{ml}, 10 \mathrm{ml}, 20 \mathrm{ml}, 30 \mathrm{ml}$. Pengujian ini dilakukan pada temperatur standar $37^{\circ} \mathrm{C}$.

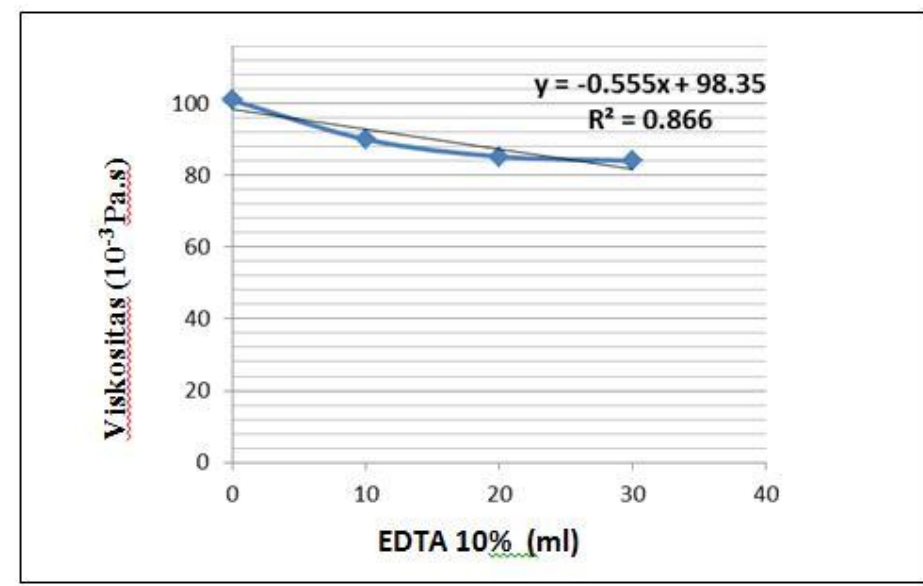

Gambar 4 Hasil pengujian viskositas darah menggunakan metode falling ball viscometer small tube variasi pencampuran EDTA 10\%

Grafik hasil pengujian dari pengukuran viskositas darah dengan pengaruh pencampuran EDTA $10 \%$ dilihat pada Gambar 4. Nilai viskositas yang didapatkan dari alat ukur yang dibuat menghasilkan nilai fungsi transfer $y=-0,555 x+98,35$ dengan nilai regresi 0,866 . Dapat dilihat bahwa semakin banyak pencampuran EDTA $10 \%$ maka semakin kecil nilai viskositasnya

\subsection{Pengujian Alat Menggunakan Ethernet Shield}

Hasil viskositas darah yang dirancang akan ditransmisikan ke PC melalui ethernet shield. Ethernet shield berfungsi sebagai pengirim IP address ke PC, sehingga data yang telah diolah oleh Arduino Uno dapat dilihat pada PC dengan mengetikan IP adress pada web browser. IP address tersebut merupakan IP address yang telah diberikan oleh Ethernet shield. Hasil pengukuran dapat dilihat pada Tabel 1 dan Tabel 2.

Tabel 1 Data viskositas darah yang ditransmisikan dengan Ethernet shield variasi temperatur

\begin{tabular}{ccc}
\hline Pengukuran & Temperatur $\left({ }^{\mathbf{0}} \mathrm{C}\right)$ & $\begin{array}{c}\text { Viskositas darah } \\
\text { dengan transmisi Ethernet shield }\end{array}$ \\
\hline I & 30 & 106 \\
II & 37 & 101,6 \\
III & 43 & 100 \\
\hline
\end{tabular}


Tabel 2 Data viskositas darah yang ditransmisikan dengan Ethernet shield variasi EDTA $10 \%$

\begin{tabular}{ccc}
\hline Pengukuran & $\begin{array}{c}\text { Pencampuran } \\
\text { EDTA 10\% }(\mathbf{m l})\end{array}$ & $\begin{array}{c}\text { Viskositas darah } \\
\text { dengan transmisi Ethernet shield }\end{array}$ \\
\hline I & $10: 40$ & 92 \\
II & $20: 40$ & 84 \\
III & $30: 40$ & 79,2 \\
\hline
\end{tabular}

Hasil yang didapatkan menunjukan bahwa ethernet shield dapat berperan dalam pengiriman data. Data yang ditransmisikan dapat diakses oleh PC dengan menggunakan jaringan yang sama.

\subsection{Perbandingan Nilai Alat Ukur Dengan Alat Pembanding}

Pengujian alat ukur ini bertujuan untuk mengetahui ketepatan hasil pengukuran viskositas darah yang diperoleh antara alat ukur yang dirancang menggunakan metode falling ball viscometer small tube dengan Viskometer Stormer. Perbandingan nilai alat ukur dengan alat pembanding dilihat pada pengujian viskositas dengan variasi temperatur.

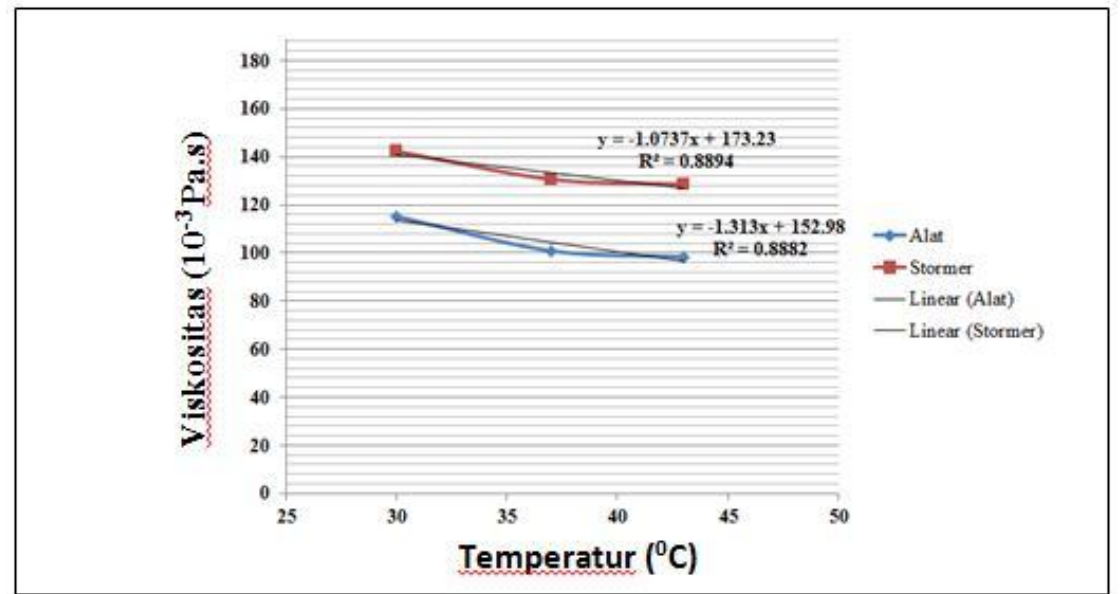

Gambar 5 Perbandingan hasil pengujian viskositas darah menggunakan metode falling ball viscometer small tube dengan viskometer stormer variasi temperatur

Grafik hasil pengujian dari pengukuran viskositas darah dengan pengaruh variasi temperatur dilihat pada Gambar 5. Pengujian viskositas darah dengan viskometer stormer didapatkan nilai fungsi transfernya yaitu $y=-1,0737 x+173,23$ dengan nilai regresi nya 0,8894 sementara itu nilai viskositas yang didapatkan dari alat ukur yang dibuat menghasilkan nilai fungsi transfer $y=-1,313 x+152,98$ dengan nilai regresi 0,8882 .

Pada hasil perbandingan nilai viskositas dengan alat ukur yang dirancang dengan viskometer stormer masih memiliki nilai error cukup besar yaitu 21,73\%. Hal ini disebabkan waktu yang diukur pada viskometer stormer menggunakan stopwatch sehingga peluang terjadinya human error cukup besar. Berbeda dengan alat yang dibuat, waktu dihitung secara digital dengan sensor fotodioda.

Kesalahan yang terjadi pada sistem diakibatkan oleh kesalahan teknis dalam proses pengukuran nilai viskositas darah, seperti pada saat mengukur nilai viskositas pada viskometer stormer sebagai alat pembanding, dimana pada alat ini masih menggunakan stopwatch sebagai timer sehingga mengakibatkan human error. Kesalahan berikutnya yang terjadi yaitu pada saat pengukuran temperatur LM35 waterproof yang tidak terletak di dalam tabung alat, karena sensor LM35 berukuran cukup besar dari tabung pipet kaca, oleh karena itu sensor temperatur LM35 hanya bisa mendeteksi temperatur di wadah yang berbeda.

\section{KESIMPULAN}

Berdasarkan pengujian dan analisis yang telah dilakukan maka diperoleh kesimpulan yaitu alat ukur viskositas darah berbasis metode falling ball viscometer small tube menggunakan 156 
transmisi ethernet shield telah berhasil dirancang bangun. Sensor temperatur LM35 yang digunakan dapat bekerja dengan baik, dengan nilai regresi yang didapat pada temperatur naik sebesar 0,977 dan pada temperatur turun nilai regresinya 0,9997. Semakin tinggi nilai temperatur maka semakin menurun nilai viskosits darahnya, dan sebaliknya. Semakin banyak penambahan EDTA 10\% maka semakin kecil juga nilai viskositas darah. Data dari alat telah dapat ditransmisikan dan ditampilkan di web browser PC menggunakan ethernet shield.

\section{DAFTAR PUSTAKA}

Giancoli, D.C., Physics, (diterjemahkan oleh: Yuhilza H.), Erlangga, Jakarta, 1998.

Kesmarky, G., Peter, K., Miklos, R. dan Kalman, K., Plasma viscosity: A forgotten variable, Clinical Hemorheology and Microcirculation 39 (2008) 243-246s, Department of Medicine, University of Pecs, Hungary, 2008.

Kim, W.J, Kim, S., Huh, C., Kyu, B.K., Jun dan W.K., A Novel hand -held viscometer applicable for point of care, Sensor and actuator B, Elsevier, 239-246, Universitas Hansung, Korea Selatan, 2016.

Nurhandie, Z., Rancang Bangun Alat Ukur Viskositas Darah dengan Sensor PPG (Photopletysmograph), Skripsi, Fisika, Universitas Airlangga, Surabaya, 2016. 